\title{
The problems and countermeasures of the application of instructional design theory in teaching practice
}

\author{
Changping Wang ${ }^{1, a}$, Chunbo Wei ${ }^{* 2, b}$,Jianbo Wang ${ }^{1, c}$, Pengxia Zhang ${ }^{1, d}$ \\ ${ }^{1}$ College of Life Science, Jiamusi university, Hei Longjiang, Jiamusi,China, 154007 \\ ${ }^{2}$ College of Animal Science and Technology, Hei Longjiang Bayi Agricultural University, Hei \\ Longjiang, daqing,China, 163319 \\ awcp100200@163.com, 'beicb298@163.com, cwangjianbo-2000@163.com, ${ }^{\text {b }}$ pengxiaz@163.com \\ ${ }^{*}$ Corresponding author
}

\begin{abstract}
Keywords: instructional design theory; teaching practice; problem; countermeasure
Abstract: The author found that the problems of the application of instructional design theory in teaching practice as follows:(1)Instructional design theory guides the teaching practice operability weakly;(2)The theory of teaching design and the current teaching practice is very difficult to achieve the same level in our country;(3)The capacity of teachers using instructional design theory is limited;(4)The students and teachers' creativity has been restricted in the teaching process;(5)Teaching design system concept closure. The author found that the countermeasures of the application of instructional design theory in teaching practice as follows:(1)Further strengthen the practice research of teaching design;(2) Pay attention to the teaching design; (3)Advocate the teaching design of information;(4)Teachers should take initiative to improve the level of teaching design;(5)Strengthen the further training of instructional design theory.
\end{abstract}

\section{Introduction}

Instructional design theory itself has a certain abstraction. Teaching practice is specific and complex in the process of teaching practice.It is possible that instructional design theory is not suited to teaching practice.There are many problems on domestic instructional design theory application in teaching practice because the practice of instructional design theorists type is diversity.We must take appropriate measures to deal with the problems.

\section{The application problem of instructional design theory in teaching practice}

\section{Instructional design theory guides the teaching practice operability weakly}

Instructional design theory is often more abstract and macro.So these limited theory once were linked the teaching practices, it lacks operability Practice.

The theory of instructional design is more abstract and macroscopic. The three processes of teaching design are prophase analy, teaching strategies and teaching evaluation, which are just macroscopic description.The three processes of teaching design did not provide the research methods and tools. Teachers can only try to figure out the model of instructional design process according to the former teaching experience. Although currently in China, there are many experts and scholars in this field who made a lot of useful work, but most of the teaching design is based on the traditional teaching center, can not meet the requirements of quality education.

The theory of teaching design and the current teaching practice is very difficult to achieve the same level in our country

The theory of instructional design reflects the development of the educational concept, learning theory and teaching mode in the west, and promotes to cultivate students' creativity and scientific spirit.

Our country has already formed the "Confucian" education concept and learning theory for thousands of years in the current teaching practice in our country. The education practice in our country is mainly oriented to exam oriented education, which emphasizes students' mastery knowledge. Thus the theory 
of teaching design in the West and the current teaching practice in our country are very difficult to achieve the same level.

\section{The capacity of teachers using instructional design theory is limited}

In the process of popularization and promotion of teaching design theory, we deeply realize that the theory of instructional design is abstract and macro. And it is difficult to grasp its essence.Many teachers did not fully grasp teaching design basic theory and steps. Young teachers can not start when they do teaching design.Successful teaching design cases often become a mere formality.The role of teaching design cases is very limited in the actual teaching.

The theory of instructional design requires that teachers should carry out the analysis of learning behavior, the design of learning tasks, the design of learning environment and the teaching goal of comprehensive teaching. These tasks are highly creative and challenging, and are not easily accomplished by a single teacher. In our reality, there is a certain gap between the quality of instructional designers and the theory of instructional design.

The students and teachers' creativity has been restricted in the teaching process

The theory of instructional design promotes the standardization and standardization in the teaching process. The mode of instructional design is only the reference frame of the teaching standard, and it is not a strict industrial practice. But the current teaching design patterns and tools is the form of forms and processes in our country.This pattern has seriously restricted the production of teachers and students' creative thinking, and also imprisoned the formation of divergent, critical and creative thinking.

The instructional design in our country are mostly based on to improve the teaching effect, complete consideration of specific teaching objectives. The instructional design focus on the design of "how to teach", rarely combinated teaching system with the external environment.

\section{Teaching design system concept closure}

Our teaching design idea is based on the completion of the teaching goal.ignoring the importance of improving the teaching effect.Teachers pay more attention to the improvement of the teaching system itself, little attention has been given to the students' external environment, social development and students in the learning process. Teaching design idea has not combinated quality education.Our design concept is enclosed in the teaching system of self loop,seldom extend outward, lest affected the completion of the teaching goals.

\section{The Countermeasures of the application of Instructional design theory in Teaching Practice}

\section{Further strengthen the practice research of teaching design}

Teachers often find that there is a distance between teaching theory and teaching practice.Educational theory researchers focus on the descriptive theory while teaching is a very practical work, teaching design theory is targeted.At present, the teaching theory research mainly adopts the qualitative and quantitative method. It want to create descriptive knowledge education. Therefore, we need to carry out an empirical study based on the theory of instructional design in teaching practice. The empirical study can guarantee the theory of instructional design meet the need of teachers teaching, improve our ability to change the status quo.

\section{Pay attention to the teaching design}

Instructional design evaluation is a very important part of instructional design theory. Instructional design evaluation should evaluate the various aspects of instructional design through formative assessment and terminating evaluation.Every teaching design activity is approaching the baseline value through feedback to promote its constantly revised and improved.Therefore, in order to improve the teaching quality, the school regulations should include the teaching design evaluation standard.The school also make it become one of the important indicators to evaluate the teaching work.

\section{Advocate the teaching design of information}

System theory methods is used at information instructional design, it promote the student to transformate their learning style,use modern information technology and information resources fully 
and properly, arrange all aspects and elements of the teaching process, realize the optimization of teaching process. The information instructional design includes teaching plan, teaching plan execution, teaching activity evaluation and feedback.

\section{Teachers should take initiative to improve the level of teaching design}

Most teachers hope to improve their design teaching ability through practice, also hope to master the theory of instructional design, and combine theory with practice through training soon. Teachers must pay attention to the cultivation of teaching ability, find the importance of instructional design, enrich their knowledge on the relevant theories of instructional design. Teachers should improve their teaching design, play their own initiative, discuss with other teachers, learn from other teachers,exchange teaching experience.On the other hand,teachers also should communicate with students, understand the students thinking, often reflect, form a good relationship between teachers and students. Only in this case, most teachers can continue to obtain the most real and effective information, and effectively improve the level of teaching design.

\section{Strengthen the further training of instructional design theory}

Education authorities should be appropriate to invest in the teaching design,develop the teaching design theory training for the teachers, promote the popularization of teachers "teaching design" theory and technology, improve the level of educational technology through training classes, lectures, competitions.In the teaching of Normal University, it is necessary to increase the content of teaching design,let teachers understand the teaching.

\section{Acknowledgements}

The job is sponsored by the educational and teaching reform project of Heilongjiang Province Education Department (GJZ201301035), by the Heilongjiang province degree and graduate education teaching reform research guidance project (JGXM_HLJ_2012116) and the "twelfth five-year" plan key project of Hei Longjiang Provincial Education Science (GJB1215054) .

\section{References}

[1]X Mai:The theory and methods of teaching design.Guangzhou: New Century Press, (1996).

[2] X.S.Zhou, X.Y.Yan:Design ideas and teaching mode of new curriculum design. Sichuan: Sichuan University press, (2002).

[3] Q.L.Sheng,Z.Q.Li :Modern teaching design theory . Zhejiang Education Press, (1998).

[4]W.Huang.Comparative Education Research,Vol.8(2001).p16-19.

[5] M.N.Wu. Instructional design. Beijing: Higher Education Press, (1993).

[6]K.K.He. The Chinese audio-visual education,Vol.10(1998).p9-11.

[7] M.F.Liu. China audio-visual education,Vol.10(2001).p11.

[8]W.Gao. China audio-visual education,Vol.2(2005).p13-14.

[9] M.DavidMer rill, Z.M.Li \& Mark K. Jones. Educational Technology, Vol.1(1990).p7-11.

[10] M.DavidMer rill, Z.M.Li \& Mark K. Jones. Educational Technology, Vol.2(1990).p7-14.

\section{Author Introduction}

The first author: Changping Wang , 1978, male, associate professor.major study field: livestock production management and animal welfare, e-mail:wcp100200@163.com.

Corresponding author: Chunbo Wei, e-mail:weicb298@163.com. 